\title{
Ефективність ранолазину у комплексному лікуванні пацієнтів із хронічним коронарним синдромом, хронічним обструктивним захворюванням легень та ожирінням
}

\section{І.Л. Неміш}

Буковинський державний медичний університет, Чернівці, Україна

\begin{abstract}
Анотація. Мета: вивчення ефективності ранолазину у складі комплексної терапії шляхом оцінки його впливу на показники ліпідограми, функціонального стану ендотелію, рівень N-кінцевого фрагмента попередника мозкового натрійуретичного пептиду (NT-proBNP) при коморбідному поєднанні хронічного коронарного синдрому, хронічного обструктивного захворювання легень та ожиріння. Об'єкт і методи дослідження. Учасників дослідження $(\mathrm{n}=30)$ було рівномірно розподілено у дві групи: 1-шу (контрольну), в якій пацієнтам призначали стандартну терапію, та 2-гу (основну), в якій хворі додатково у складі комплексної терапії застосовували ранолазин у дозі 500 мг 2 рази на добу протягом 1 міс. Контрольну групу становили 20 практично здорових осіб. Результати. Після лікування показники загального холестерину та коефіцієнту атерогенності були на 8,6\% $(p<0,05)$ та на 14,5\% (p<0,05) нижчими в основній групі порівняно з контрольною. Через 1 міс лікування у хворих 2-ї групи виявлено зниження на 5,9\% ( $<<0,05)$ рівня NT-proBNP, зростання на $21,6 \%(p<0,05)$ вмісту стабільних метаболітів оксиду азоту (NO), на $32,6 \%(p<0,05)$ рівня $\mathrm{NO}_{3}(\mathrm{p}<0,05)$, зниження на $3,6 \%(\mathrm{p}<0,05)$ рівня ендотеліну- 1 . Висновок. Застосування ранолазину у складі комплексної терапії сприяє покращанню показників ліпідного спектра плазми крові (зниженню рівня загального холестерину та коефіцієнту атерогенності), функціонального стану ендотелію (підвищенню рівня $\mathrm{NO} \mathrm{NO}_{3}$, зниженню рівня ендотеліну-1) та зниженню рівня NT-proBNP у пацієнтів із хронічним коронарним синдромом, хронічним обструктивним захворюванням легень та ожирінням.
\end{abstract}

Ключові слова: хронічний коронарний синдром, хронічне обструктивне захворювання легень, ожиріння, N-кінцевий фрагмент попередника мозкового натрійуретичного пептиду, ранолазин.

\section{Вступ}

При веденні пацієнтів із хронічним коронарним синдромом (ХКС), хронічним обструктивним захворюванням легень (ХОЗЛ) та ожирінням важливо обирати терапію, спрямовану не тільки на зменшення вираженості симптомів захворювання, але й на корекцію порушень ліпідного обміну та спільних ланок патогенезу (зокрема дисфункції ендотелію, характерної для багатьох хронічних захворювань) [1]. При аналізі даних літературних джерел встановлено, що однією з проблем вибору терапії у цієї групи хворих $\epsilon$ наявність певних обмежень щодо застосування блокаторів $\beta$-адренорецепторів у зв'язку 3 можливим розвитком побічних ефектів з боку дихальної системи [2], а також агоністів $\beta_{2}$-адренорецепторів тривалої дії через їх ймовірний вплив на підвищення ризику розвитку несприятливих серцево-судинних подій [3]. У рекомендаціях Європейського товариства кардіологів (European Society of Cardiology - ESC) 2019 р. зазначено, що у хворих на ХКС при наявності протипоказань до застосування препаратів 1-ї лінії існує можливість розглядати призначення лікарських засобів 2-ї лінії, до яких належить ранолазин, вивчення якого при ХКС, ХОЗЛ та ожирінні $\epsilon$ актуальним у зв'язку з необхідністю пошуку найбільш оптимальної та безпечної терапії у цієї групи пацієнтів [4].

Мета дослідження: вивчення ефективності ранолазину у складі комплексної терапії шляхом оцінки його впливу на показники ліпідного спектра плазми крові, функціонального стану ендотелію та рівень N-кінцевого фрагмента попередника мозкового натрійуретичного пептиду (NT-proBNP) при коморбідному поєднанні ХКС, ХОЗЛ та ожиріння.

\section{Об'єкт і методи дослідження}

Учасників дослідження $(\mathrm{n}=30)$ було рівномірно розподілено у дві групи: 1-шу (контрольну), в якій пацієнтам призначали стандартну терапію, та 2-гу (основну), в якій хворим до складу комплексної терапії додавали ранолазин у дозі 500 мг 2 рази на добу протягом 1 міс. Контрольну групу становили 20 прак- тично здорових осіб (ПЗО). Учасникам обох груп призначено базисну терапію ХКС згідно з рекомендаціями ESC 2019 р. та ХОзЛ - відповідно до адаптованої клінічної настанови з ХОЗЛ Національної академії медичних наук України від 21.01.2020 р. та Глобальної ініціативи з ХОЗЛ (Global Initiative for Chronic Obstructive Lung Disease - GOLD) 2021 р. 3 метою вивчення ліпідного спектра плазми крові (рівня загального холестерину (3Х), тригліцеридів (ТГ), холестерину ліпопротеїдів високої (ХС ЛПВЩ) та низької щільності (ХC ЛПНЩ) використовувати діагностичні набори реагентів («PZ Cormay S.А.», Польща). Визначення вмісту у крові стабільних метаболітів оксиду азоту (NO) проводили методом L.C. Green та співавторів (1982), кількості циркулюючих злущених ендотеліоцитів - методом J. Hladovec (1978) у модифікації Н.Н. Петрищева та співавторів (2001). Рівень розчинної форми молекули адгезії ендотелію судин 1-го типу (sVCAM-1), ендотеліну-1 (ET-1) та NT-proBNP у сироватці крові вивчали за допомогою імуноферментного методу з використанням наборів реактивів («Bender MedSystems», Австрія, «Biomedica Medizinprodukte GmbH and Co KG», Австрія, та «Ruilai Biological Engineering (Шеньчжень) Лтд» відповідно).

Статистичну обробку отриманих результатів проведено за допомогою програми «Statistica 10». Кількісні дані представлені у вигляді $\mathrm{Me}\left(\mathrm{Q}_{25}-\mathrm{Q}_{75}\right)$, де $\mathrm{Me}-$ медіана, $\mathrm{Q}_{25}-\mathrm{Q}_{75}-\mathrm{iH}_{-}$ терквартильний розмах. Використовували парний Т-критерій Вілкоксона з метою оцінки кількісних змін у динаміці лікування та непараметричний U-критерій Манна - Уітні при міжгруповому порівнянні отриманих даних.

\section{Результати}

Отримані результати порівняльної оцінки показників ліпідного спектра плазми крові у хворих основної та контрольної груп наведені у табл. 1.

При аналізі значень ліпідного спектра плазми крові встановлено, що через 1 міс лікування у хворих основної та контрольної груп відмічали зниження рівня 3 Х на $13 \%(p<0,05)$ 
та на 4,5\% $(\mathrm{p}<0,05)$ відповідно. При оцінці цього показника після лікування у хворих, які додатково застосовували ранолазин у складі базисної терапії, 3 Х був на $8,6 \%(p<0,05)$ нижчим при порівнянні з особами, які отримували стандартну терапію.

Через 1 міс відмічали зниження рівня ТГ на 13\% $(p<0,05)$ та на $9 \%(p<0,05)$ у пацієнтів 2-ї та 1-ї груп відповідно. Після 30-денного лікування ХС ЛПНЩ був на $10,7 \%(p<0,05)$ та на $8,47 \%(p<0,05)$ нижчим, а ХС ЛПВЩ - на $4,8 \%(p<0,05)$ та на $2 \%(p<0,05)$ вищим в учасників основної та контрольної груп відповідно. Через 1 міс лікування коефіцієнт атерогенності (КА) виявився на $19,3 \%(p<0,05)$ та на $7,2 \%(p<0,05)$ нижчим у хворих 2-ї та 1-ї груп відповідно. При оцінці значень цього показника після завершення терапії відмічали зниження на $14,5 \%(p<0,05)$ КА в основній групі при порівнянні з контрольною.

При оцінці ефективності додаткового призначення ранолазину у складі комплексної терапії через 1 міс лікування відмічали також зниження на 5,9\% $(p<0,05)$ рівня NT-proBNP у хворих 2-ї групи порівняно з 1-ю, у якій вірогідної різниці між значеннями цього показника до та після лікування не виявлено $(p>0,05)$ (рисунок).

Рисунок Рівні NT-proBNP у хворих контрольної та основної груп

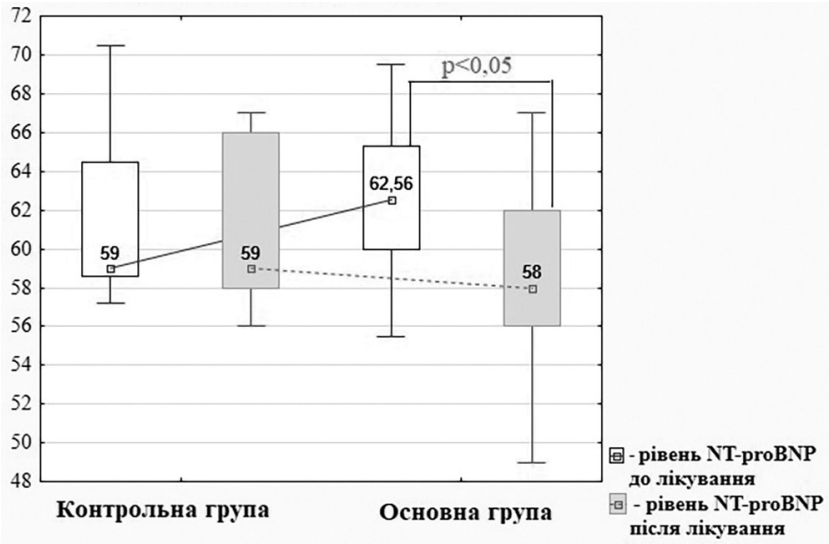

При аналізі показників функціонального стану ендотелію отримані результати, представлені у табл. 2.

Через 1 міс лікування у пацієнтів основної групи відмічали покращання показників функціонального стану ендотелію (зростання на $21,6 \%(p<0,05)$, на $32,6 \%(p<0,05)$ вмісту стабільних метаболітів NO та рівня $\mathrm{NO}_{3}$ відповідно, зниження на $3,6 \%(p<0,05)$ рівня ЕT-1), при цьому у групі контролю статистично значущої різниці між цими значеннями до та після лікування не відмічено $(p>0,05)$.

\section{Обговорення}

Механізм дії ранолазину при ішемії полягає у пригніченні пізньої фази потоку натрію у кардіоміоцити, що сприяє запобіганню перевантаженню клітин міокарда кальцієм та натрієм, зниженню потреби міокарда в кисні, зменшенню кількості та тривалості ангінозних нападів та підвищенню толерантності до фізичних навантажень [5]. 3 іншого боку, ранолазин сприяє обмеженню застосування вільних жирних кислот як енергетичного субстрату (енергоутворення шляхом $\beta$-окиснення жирних кислот потребує високих затрат енергії) та посиленню утилізації глюкози, що забезпечує підтримку енергетичного потенціалу клітин міокарда [6].

Отримані нами результати дослідження при коморбідному поєднанні ХКС, ХОЗЛ та ожиріння схожі з даними Н.М. Шуби та співавторів (2017), в яких зазначається про позитивний вплив ранолазину на показники ліпідного спектра плазми крові у пацієнтів із стабільною стенокардією напруги [7]. Останніми роками увага науковців також зосереджена на встановленні прогностичного значення NT-proBNP у ранній діагностиці несприятливих кардіоваскулярних подій та загострень ХОЗЛ $[8,9]$. У нашому дослідженні відмічено зниження рівня NT-proBNP при додатковому застосуванні ранолазину у хворих основної групи, що, можливо, свідчить про позитивний вплив препарату щодо запобігання загостренням у пацієнтів цієї групи. У літературі також $\epsilon$ дані про покращання показників ендотелійзалежної та ендотелійнезалежної вазодилатації судин при застосуванні ранолазину у пацієнтів з ішемічною хворобою серця [10]. у нашому дослідженні також показано переваги застосування препарату у складі комплексної терапії при коморбідному поєднанні ХКС, ХОЗЛ та ожиріння щодо покращення показників функціонального стану ендотелію (підвищення вмісту стабільних метаболітів $\mathrm{NO}, \mathrm{NO}_{3}$, зниження рівня $\mathrm{ET}-1$ ).

\section{Висновок}

Застосування ранолазину у складі комплексної терапії при коморбідному поєднанні ХКС, ХОЗЛ та ожиріння сприяє покращанню показників ліпідного спектра плазми крові (зниженню рівня $3 \mathrm{X}$ та КА), функціонального стану ендотелію (підвищенню вмісту стабільних метаболітів $\mathrm{NO}$, рівня $\mathrm{NO}_{3^{\prime}}$ зниженню рівня ET-1), а також зниженню рівня NT-proBNP.

Таблиця 1 Показники ліпідного спектра плазми крові у хворих основної та контрольної груп у динаміці лікування

\begin{tabular}{|c|c|c|c|c|c|}
\hline \multirow{2}{*}{ Показник } & \multirow{2}{*}{$\begin{array}{l}\Pi 30 \\
n=20\end{array}$} & \multicolumn{2}{|c|}{ Контрольна група (1-ша), n=15 } & \multicolumn{2}{|c|}{ Основна група (2-га), n=15 } \\
\hline & & До лікування & Після лікування & До лікування & Після лікування \\
\hline 3Х, ммоль/л & $4,9[4,4 ; 5,1]$ & $6,9[6,6 ; 7,2]$ & $6,5[6,3 ; 7]^{*}$ & $7[6,4 ; 7,2]$ & $6,2[5,6 ; 6,5]^{* / * *}$ \\
\hline ТГ, ммоль/л & $1,66[1,18 ; 1,75]$ & $3,44[3,25 ; 3,78]$ & $3,24[3 ; 3,63]^{*}$ & $3,4[3,25 ; 3,95]$ & $3[2,7 ; 3,3]^{*}$ \\
\hline ХС ЛПНЩ, ммоль/л & $2,47[1,8 ; 2,5]$ & $3,9[3 ; 4]$ & $3,5[2,67 ; 3,7]^{*}$ & $3,5[3 ; 4,38]$ & $3[2,5 ; 4,1]^{*}$ \\
\hline ХС ЛПВЩ, ммоль/л & $1,27[1,22 ; 1,41]$ & $1,02[0,98 ; 1,04]$ & $1,04[1 ; 1,07]^{*}$ & $1[0,98 ; 1,02]$ & $1,07[1 ; 1,09]^{*}$ \\
\hline KA & $2,5[2,3 ; 3,3]$ & $5,8[5,47 ; 6,04]$ & $5,2[5,1 ; 5,67]^{*}$ & $5,9[5,3 ; 6]$ & $4,87[4,4 ; 5]^{* * * *}$ \\
\hline
\end{tabular}

*Вірогідність різниці при порівнянні даних ліпідограми до та після лікування; **вірогідність різниці при порівнянні даних ліпідограми між основною та контрольною групами після лікування.

Таблиця 2 Показники функціонального стану ендотелію у пацієнтів основної та контрольної груп у динаміці лікування

\begin{tabular}{|c|c|c|c|c|c|}
\hline \multirow{2}{*}{ Показник } & \multirow{2}{*}{$\Pi 30, n=20$} & \multicolumn{2}{|c|}{ Контрольна група (1-ша), n=15 } & \multicolumn{2}{|c|}{ Основна група (2-га), n=15 } \\
\hline & & До лікування & Після лікування & До лікування & Після лікування \\
\hline Вміст стабільних метаболітів N0, мкмоль/л & $27[25 ; 28]$ & $19[15 ; 20]$ & $20[13 ; 20]$ & $11,5[10 ; 14,5]$ & $14[13 ; 17]^{*}$ \\
\hline $\mathrm{NO}_{2^{\prime}}$ мкммоль/л & $11,5[9 ; 12]$ & $7[5 ; 7]$ & $7[5 ; 8]$ & $4[3 ; 6]$ & $5[3 ; 6]$ \\
\hline $\mathrm{NO}_{3}$, мкмоль/л & $15,5[14 ; 19]$ & $12[10 ; 14]$ & $13[9 ; 14]$ & $8[6 ; 9,5]$ & $11[8 ; 12]^{*}$ \\
\hline ЕТ-1, пмоль/л & $0,033[0,016 ; 0,04]$ & $0,188[0,187 ; 0,202]$ & $0,19[0,185 ; 0,201]$ & $0,193[0,18 ; 0,21]$ & $0,188[0,17 ; 0,2]^{*}$ \\
\hline Кількість циркулюючих злущених ендотеліоцитів, 104/л & $5[4 ; 5,5]$ & $20[18 ; 21]$ & $19[18 ; 21]$ & $19[18 ; 21]$ & $19[18 ; 20]$ \\
\hline sVCAM-1, нг/мл & $480[450 ; 525]$ & $2830[2550 ; 3000]$ & $2825[2560 ; 2998]$ & $2760[2700 ; 2900]$ & $2756[2715 ; 2896]$ \\
\hline
\end{tabular}

*Вірогідність різниці при порівнянні показників функціонального стану ендотелію до та після лікування; **вірогідність різниці при порівнянні показників функціонального стану ендотелію між основною та контрольною групами після лікування. 


\section{Список використаної літератури}

1. Васина Л.В., Петрищев Н.Н., Власов Т.Д. (2017) Эндотелиальная дисфункция и ее основные маркеры. Регионарн. кровообр. и микроцирк., 16(1):4-15.DOI: 10.24884/16826655-2017-16-1-4-15.

2. Fesenko 0., Bogatska K. (2018) Safety of nebivolol and bisoprolol in patients (pts) with COPD and stable angina. Eur. Respir. J., 52(suppl. 62): PA738. D0I: 10.1183/13993003. congress-2018.

3. Suissa S., Dell'Aniello S., Ernst P. (2017) Concurrent use of long-acting bronchodilators in COPD and the risk of adverse cardiovascular events. Eur. Respir. J., 49: 1602245. DOl: 10.1183/13993003.02245-2016.

4. Knuuti J., Wijns W., Saraste A. et al. (2020) 2019 ESC Guidelines for the diagnosis and management of chronic coronary syndromes. Eur. Heart J., 41(3): 407-477. D01: 10.1093/eurheartj/ ehz425.

5. Дмитриева И.С., Кравченко Е.В. (2017) Лекарственное средство ранолазин в терапии стабильной стенокардии. Кардиология в Беларуси, 9(4): 719-733.

6. Щетинин П.П. (2015) Роль метаболической кардиопротекции в фармакотерапии ишемической болезни сердца. Акт. пробл. гуманит. ест. наук, 8(2): 125-129.

7. Шуба Н.М., Кир'яченко С.П., Воронова Т.Д. та ін. (2017) Визначення ефективності ранолазину та його вплив на функцію клітин у хворих з ішемічною хворобою серця. Ліки України, 7(213): 53-57.

8. Tuxunguli T., Aierken A., Xie X. et al. (2014) Association study of plasma NT-proBNP levels and severity of acute coronary syndrome. Genet. Mol. Res., 13(3): 5754-5757. DOI: $10.4238 / 2014$

9. Labaki W.W., Xia M., Murray S. et al. (2018) NT-proBNP in stable COPD and future exacerbation risk: Analysis of the SPIROMICS cohort. Respir. Med., 140: 87-93. D0I: 10.1016/j. rmed.2018.06.005.

10. Rehberger-Likozar A., Šebeštjen M. (2015) Influence of trimetazidine and ranolazine on endothelial function in patients with ischemic heart disease. Coron. Artery. Dis., 26(8): 651656. D0I: 10.1097/MCA.0000000000000272.

\section{Інформація про автора:}

Неміш Ірина Любомирівна — аспірант кафедри внутрішньої медицини Буковинського державного медичного університету, Чернівці, Україна.

Адреса для кореспонденції:

Неміш Ірина Любомирівна

58003, Чернівці, 2-й пров. Герцена, 2/34

E-mail: iranemish@ukr.net

\section{Efficacy of ranolazine in complex \\ treatment of chronic coronary syndrome, chronic obstructive pulmonary disease and obese patients}

\section{I.L. Nemish}

Bukovynian state medical university, Chernivtsi, Ukraine

Abstract.Aim: to study the effectiveness of ranolazine in complex therapy in chronic coronary syndrome, chronic obstructive pulmonary disease and obese patients. Object and methods of the study. Participants $(n=30)$ were evenly divided into two groups: 1st (control), in which patients received standard therapy, and 2nd (main), in which patients received ranolazine at a dose of $500 \mathrm{mg} 2$ times a day for 1 month additional to complex therapy. The control group consisted of 20 healthy individuals. Results. After treatment, the level of total cholesterol and atherogenic index was lower by $8.6 \%(p<0.05)$ and by $14.5 \%(p<0.05)$ in the main group compared to control. It was found a decrease by $5.9 \%(p<0.05)$ of NT-proBNP level, an increase by $21.6 \%(p<0.05)$ the content of stable metabolites of nitric oxide (NO), by $32.6 \%(\mathrm{p}<0.05) \mathrm{NO}_{3}$, a decrease by $3.6 \%(\mathrm{p}<0.05)$ the level of endothelin-1 in the second patients' group. Conclusion. The use of ranolazine in complex therapy improves the plasma lipid spectrum (decrease total cholesterol and atherogenic index levels), endothelial function (increase the content of stable metabolites $\mathrm{NO}, \mathrm{NO}_{3^{\prime}}$ decrease endothelin-1), and reduces NT-proBNP in chronic coronary syndrome, chronic obstructive pulmonary disease, and obese patients.

Key words: chronic coronary syndrome, chronic obstructive pulmonary disease, obesity, $\mathrm{N}$-terminal fragment of the precursor of brain natriuretic peptide, ranolazine.

\section{Information about the author:}

Nemish Iryna L. — postgraduate student, Department of Internal Medicine, Bukovynian State Medical University, Chernivtsi, Ukraine.

\section{Address for correspondence:}

Iryna Nemish

58003, Chernivtsi, 2-nd Herzen's lane, 2/34

E-mail: iranemish@ukr.net 